\title{
PHASE II CALDERON PROCESS TO PRODUCE DIRECT REDUCED IRON RESEARCH AND DEVELOPMENT PROJECT
}

Report Type: QUARTERLY Reporting Period Start Date:10/01/2005 End Date: 12/31/2005

Principal Author(s): ALBERT CALDERON

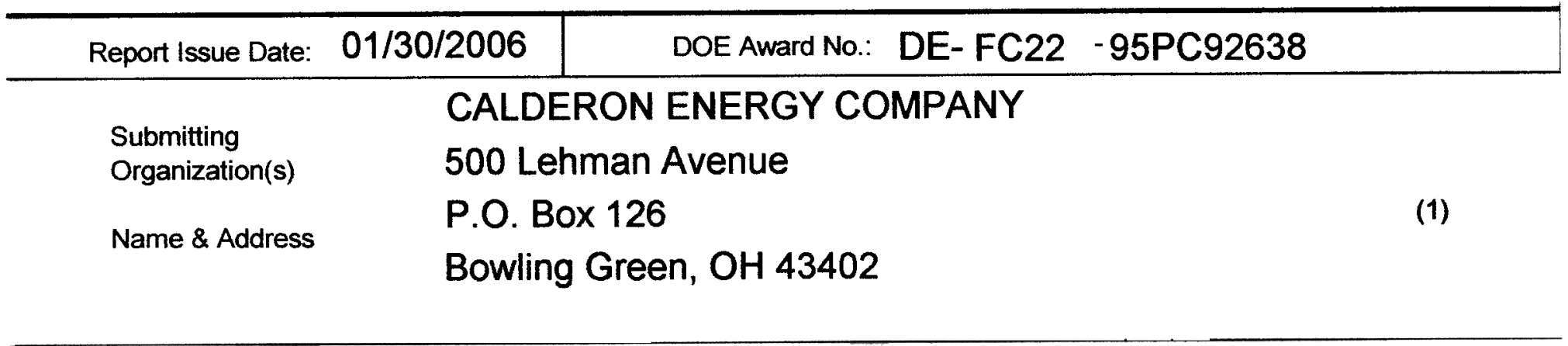

(2)

(3)

(4) 


\section{DISCLAIMER}

This report was prepared as an account of work sponsored by an agency of the United States Government. Neither the United States Government nor any agency thereof, nor any of their employees, makes any warranty, express or implied, or assumes any legal liability or responsibility for the accuracy, completeness, or usefulness of any information, apparatus, product, or process disclosed, or represents that its use would not infringe privately owned rights. Reference herein to any specific commercial product, process, or service by trade name, trademark, manufacturer, or otherwise does not necessarily constitute or imply its endorsement, recommendation, or favoring by the United States Government or any agency thereof. The views and opinions of authors expressed herein do not necessarily state or reflect those of the United States Government or any agency thereof. 


\section{QUARTERLY TECHNICAL PROGRESS REPORT \\ PHASE II CALDERON PROCESS TO PRODUCE DIRECT REDUCED IRON RESEARCH AND DEVELOPMENT PROJECT \\ CALDERON ENERGY COMPANY \\ COOPERATIVE AGREEMENT NO. DE-FC22-95PC92638}

Reporting Period: 10-01-05 to 12-31-05

Date of Report: 1-30-06;

Phase II Award Date: 6-23-00; Anticipated Completion Date: 12-03-06

Total Project: $\$ 14,732,316.00$ Total DOE Share This Action: $\$ 6,457,000.00$

Contracting Officer's Representative (COR): John Stipanovich;

Project Director: Albert Calderon

Assistant Project Director: Reina Calderon

\section{$\underline{\text { Abstract }}$}

This project was initially targeted to the making of coke for blast furnaces by using proprietary technology of Calderon in a phased approach, and Phase I was successfully completed. The project was then re-directed to the making of iron units. In 2000 , U.S. Steel teamed up with Calderon for a joint effort to produce directly reduced iron with the potential of converting it into molten iron or steel consistent with the Roadmap recommendations of 1998 prepared by the Steel Industry in cooperation with the Department of Energy by using iron ore concentrate and coal as raw materials, both materials being appreciably lower in cost than using iron pellets, briquettes, sinter and coke. 


\section{TABLE OF CONTENTS}

Executive Summary

Experimental

Results and Discussion

Conclusion

References
Page 1

Page 2

Page 3

Page 6

Page 6 


\section{Executive Summary}

The commercialization path of the Calderon technology for making a feedstock for steelmaking with assistance from DOE initially focused on making coke and work was done which proved that the Calderon technology is capable of making good coke for hard driving blast furnaces. U.S. Steel which participated in such demonstration felt that the Calderon technology would be more meaningful in lowering the costs of making steel by adapting it to the making of iron - thus obviating the need for coke.

U.S. Steel and Calderon teamed up to jointly work together to demonstrate that the Calderon technology will produce in a closed system iron units from iron concentrate (ore) and coal competitively by eliminating pelletizing, sintering, coking and blast furnace operation. If such process steps could be eliminated, a huge reduction in polluting emissions and greenhouse gases (including $\mathrm{CO}_{2}$ ) relating to steelmaking would ensue. Such reduction will restructure the steel industry away from the very energy-intensive steelmaking steps currently practiced and drastically reduce costs of making steel.

The development of a technology to lower U.S. steelmaking costs and become globally competitive is a priority of major importance. Therefore, the development work which Calderon is conducting presently under this Agreement with the U.S. Department of Energy becomes more crucial than ever.

During the 4th quarter of 2005 which the present report covers, virtually all the effort to advance the Calderon technology to make iron units was concentrated towards forming a team with a steelmaker who needs both iron units in the form of hot metal and a substitute for natural gas (SNG), both being major contributors to higher costs in steelmaking. Calderon felt that a very good candidate would be Steel Dynamics (SDI) by virtue that it operates a rotary 
hearth facility in Butler, Indiana that uses large amounts of natural gas to reduce briquettes made from ore and coal that they subsequently melt in a submerged arc furnace that is a large consumer of electric power. This facility is operated as a division of SDI under the name of Iron Dynamics (IDI). It is no secret that IDI has had and still has a great number of operational problems, including high cost for natural gas.

\section{Experimental}

During the $4^{\text {th }}$ quarter of 2005 which covered the work described in this report entailed the running of three tests shown in Table 1. The first Test Run was for Steel Dynamics (SDI). The second Test Run incorporated the use of nitrogen with the oxygen as a deluent, and the third for U.S. Steel.

\section{TABLE 1}

\begin{tabular}{|c|c|c|c|}
\hline Test Run \# & Date & Length in $\mathrm{Hrs}$ & No. of Pushes \\
\hline I-186 & Oct $3^{\text {rd }}$ and $4^{\text {th }}$ & $29 \mathrm{hrs}: 30$ mins & 329 \\
\hline l-187 & Oct $12^{\text {th }}$ and $13^{\text {th }}$ & $59 \mathrm{hrs}: 15$ mins & 672 \\
\hline $\mid-188$ & Oct $19^{\text {th }}$ and $20^{\text {th }}$ & $28 \mathrm{hrs}: 40 \mathrm{mins}$ & 348 \\
\hline
\end{tabular}

Ore Concentrate - Cleveland Cliffs

Coal - Elkhorn

Ratio of Ore to Coal in Mix - 3:1

Mix Weight/Push - 3.5 lbs.

Coal in Core/Push - $1 \mathrm{lb}$. 


\section{Results and Discussion:}

As stated above, Test Run I-186 was conducted for SDI; it included the making of the metallized intermediate and melting it to make hot metal which was cast into pigs. The entire cast was taken to SDI's Butler, Indiana plant for analysis.

This test experienced high pushing pressures early in the test causing delays which aggregated to a loss of 29 pushes. Instead of 329 pushes there should have been 358 pushes. Even though this test experienced the mentioned problem SDI was satisfied in the observation of the test particularly since the delays occurred early in the test, and hot metal was successfully made and cast into pigs in the presence of its representatives.

On the $5^{\text {th }}$ of October, the unit was taken apart to determine the cause for the high pushing pressures. It was found that part of the refractory in the reactor was gouged between 11 and 2 o'clock in the form of a sector. Such damage which prevents a smooth movement of the charge through the reactor had not been seen during many of the recent tests. The logs were reviewed and from the information gleaned, it was concluded that the start-up of the test had been accelerated with the injection of oxygen taking place too soon after ignition, causing the refractory to be overheated which resulted in the melting of some of the refractory from the crown of the reactor. A decision was made to run another test of $60 \mathrm{hrs}$ on the $11^{\text {th }}$ of October with slow start-up and the dilution of the oxygen with nitrogen in order not to overheat the refractory in the event of impingement.

Test Run \#I-187 was begun on the morning of the $11^{\text {th }}$ and it ended on the $13^{\text {th }}, 59$ hours after start-up. No pushing pressures were experienced. The unit was ramped up slowly by adding 90 minutes to the start-up time. The moderation with nitrogen assisted in producing 
an improved iron/carbon intermediate as observed by its grindability. No melting of product was performed during this test. The unit was shut down on schedule.

In the summer of 2005, changes in personnel occurred at U.S. Steel Research, and Ernesto Serrano, became the new technical manager of Raw Materials and Ironmaking, Process Technology Division. He had never seen the Calderon process in operation.

Test Run \#I-188 was conducted for U.S. Steel and the objective was to demonstrate to the new manager that although the iron/carbon product is not uniform, but it does become uniform when homogenized by melting it to make hot metal; the benefit that would potentially accrue could be of great value to U.S. Steel as well as other steelmakers.

The pilot was started on the $19^{\text {th }}$ of October, following the same start-up procedure as Test Run \#I-187. When U.S. Steel personnel visited the Unit on the $20^{\text {th }}$, there were no surprises; it operated quite successfully. From the Fe content in the ore to hot metal which was cast into pigs, the yield was $70.9 \%$; see Table 2 . This yield was net; it did not include the screened fines, metal in the slag, nor entrained fines in the effluent gas.

At the conclusion of the test the understanding was that U.S. Steel would give consideration to the matter of viewing the Calderon process in its entirety including the homogenization of the intermediate material, from the Fe content in the ore converted to hot metal rather than a DRI. It was concluded at the meeting of the $20^{\text {th }}$ that Calderon and U.S. Steel would get in touch with each other in late November. In view of the holidays, a meeting was set for January 10, 2006 for U.S. Steel and Calderon to discuss the matter in Monroeville at U.S. Steel's Research Center.

Because of Calderon's poor financial condition, and DOE's reluctance to make available the $\$ 6.5$ million which had been appropriated by Congress in FY 2001 for this project, but 
which were re-directed by DOE temporarily to another project, as there was no need for these funds in 2002, and U.S. Steel was reluctant to support Calderon in retrieving the $\$ 6.5$ million appropriated in FY 2001, until the three 72 hour tests had bee conducted with $80 \%$ metallization of the iron/carbon product, Calderon decided to seek funds elsewhere in order to continue to develop this promising technology. Calderon contacted Mr. Marc Millett, Vice President and General Manager of SDI and requested a meeting to explain the potential benefits that might be accrued from Calderon's technology to make hot metal directly from ore concentrate and coal without pelletizing, briquetting, the use of natural gas in the rotary hearth furnace and the excessive electric power requirement $(800 \mathrm{kWh} / \mathrm{ton})$ of the submerged arc furnace which SDI operates.

Such a meeting took place at SDl's offices on November $3^{\text {rd }}$. The technology was explained with the aid of a video. Mr. Millett asked many pertinent questions. The meeting was concluded that he would be interested in the Calderon technology but as a pre-condition that testing should be, as a start, applied to using Electric Arc Furnace dust which contains $56 \%$ iron oxide and $18 \%$ zinc oxide and some other constituents, as the feed into the reactor, in an attempt to reduce this dust to recover the iron units and the zinc. The disposal of this dust is a costly operation to SDI especially since it generates 70,0000 tons of dust/year. It was agreed that prior to such tests, Mr. Millett would visit the Bowling Green pilot after the New Year and observe a test similar to the one demonstrated to his subordinates in October (Test Run \#I-186) to determine for himself the suitability of Calderon's facility. Calderon agreed to this arrangement as it is believed that this challenging work can be beneficial in view that the iron oxide in the dust would also be processed to recover iron units while recovering zinc. 


\title{
Conclusion
}

From the above, it can be concluded that progress is being made despite the technical and financial challenges facing this development. The work plan for next Quarter is to concentrate in satisfying SDI and U.S. Steel. The funding for this work is still to be negotiated with SDI after Mr. Millett's visit. Further, an appeal will be made to DOE to return the $\$ 6.5$ appropriated to this project in FY2001, which was put as a line item through Calderon's efforts and not DOE's. Calderon agreed in 2001, to the redirection of funds appropriated for this project temporarily until needed. These funds are needed now.

Submitted by:

\begin{abstract}
Albert Calderon
\end{abstract}
Project Director

References - Not Applicable

The work performed in this quarter which the report covers, was original work. No reference material was relied upon for the work. 


\section{TABLE 2}

\section{TEST RUN\# I-188 \\ October 20, $2005^{1 \text { and } 2}$}

1. Test occurred at a window between push 306 and 349 .

2. Total No. of pushes -43

3. Ore concentrate weight/push - $2.625 \mathrm{lbs}$

4. Total ore concentrate charged in 43 pushes - $113 \mathrm{lbs}$

5. Fe in concentrate $-65 \%$

6. Fe in total ore charged $-73.5 \mathrm{lbs}$

7. Weight of total hot metal cast - $\quad 127.6 \mathrm{lbs}$

8. Weight of hot metal forming the heel $-\underline{75.5} \mathrm{lbs}$

9. Net weight of hot metal cast from Fe in concentrate charged - $\quad 52.1 \mathrm{lbs}$

10. Net Yield in hot metal made from $\mathrm{Fe}$ in concentrate $-(52.1 \mathrm{lbs} \times 100) \div 73.5 \mathrm{lbs} .=70.9 \%^{3}$

Note: ${ }^{1}$ U.S. Steel Personnel Present

${ }^{2}$ Hot intermediate material discharged from GMA and melted in induction furnace (126 lbs) to make hot metal and cast into pigs.

${ }^{3}$ Concentrate that needs to be charged in excess of theoretical requirement is $100 \%$ less $70.9 \%=29.1 \%$ 